\title{
Marginal Political Practices of Youth as a Communication Trend in the Post-Politics Era
}

\section{Blinova Olesya ${ }^{1}$, Gorbunova Yuliya ${ }^{2}$, Deviatovskaia Irina ${ }^{3}$}

${ }^{1}$ Federal State Budgetary Educational Institution of Higher Education, Ural State Pedagogical University, Ekaterinburg, Russia

2 Private Educational Establishment of Higher Education, S. Yu. Vitte Moscow University, Moscow, Russia

${ }^{3}$ Federal State Budgetary Educational Institution of Higher Education, Ural State Pedagogical University, Ekaterinburg, Russia Corresponding author: Blinova Olesya, olesyablinova79@yandex.ru

Abstract. The article examines the marginal political practices of young people as a way of communicating with the authorities. Such characteristics of political practices of young people as virulence, diversification, non-normality and hybridity have been revealed. Based on the analysis of political cases of recent years, the most popular marginal political practices, meme practices, the battle of sticker packs, hashtags, etc. have been identified. The main research method was trend watching. In the course of the study, the value-semantic grounds for the application of marginal political practices by young people and their legal regulation by the state were identified. The analysis showed that the popularity of marginal political practices as a way of communication between young people and the authorities lies in the imperfection of the organisation of power in the Russian Federation. As a result, possible steps were identified that government institutions and individual officials can take to construct a productive dialogue with young people. In the conclusion, the results of the study are summarised, including the unpredictability of the outcomes of the use of marginal practices, their excessive legalisation and social partnership as the most effective way of their constructivisation.

Keywords: marginal political practices, communication, political trends, trend watching, social partnership

\section{Introduction}

One of the factors of the formation, development and functioning of society and social systems is the communicative process, through which 
intergenerational interaction and the transfer of traditions, culture and experience are carried out and organisation of communication and joint activities is provided. In addition, communication acts as a social mechanism for the emergence and implementation of power in the society.

The term 'communication' appeared in scientific literature at the beginning of the 20th century and is understood as a means of communication of any objects of the material and spiritual world; as communication, transfer of information from person to person (interpersonal communication); as communication and exchange of information in the society (social communication) [Shibutani, 1999].

Traditionally, three forms of implementation of communication in the society are considered:

1. Communication as a dialogue of equal partners. In this case, there is an exchange of information, interaction taking into account the interests and positions of each.

2. Management as a purposeful influence of the communicator on the recipient of information. It is about the desire to change the motivation, values, goals and aspirations of the communication partner in the process of communication and to endow information with certain meanings.

3. Imitation as borrowing patterns of behaviour, communication styles, lifestyle of some members of the society by others. Thus, for example, a transfer of traditions, language, knowledge and skills from generation to generation takes place.

Depending on the goals pursued, the following communication functions in the political sphere can be distinguished:

1. Information and communication - a process of exchange of information, emotions, opinions and feelings occurs. In terms of communication between young people and the authorities, it can be used to inform about each other's positions, about the vision of the essence of a particular political event, and can be used as a feedback channel.

2. Interactive - it is characterized by the interaction of individuals in the process of interpersonal communication. It allows you to negotiate and make compromise decisions, create a lively social and political interaction, correct decisions made and react to their consequences.

3. Epistemological - it creates space for adequate transmission and perception of information, taking into account the ability of the parties to correctly interpret information; promotes recognition and knowledge 
of each other. Often, politicians misinterpret the messages of socially and politically active youth, since they speak in different categories.

4. Axiological - conditions for the exchange of spiritual values and for the formation of a single value space are created in the process of communication.

5. Regulatory - communication is a means of transferring and consolidating norms in everyday consciousness. Situations of double standards often demonstrated by officials can be regarded by young people as a variant of the norm, or contribute to the formation of destructive political practices.

6. Socio-practical - in the course of communication, the results of activities, abilities, skills are exchanged, the possession of competencies is demonstrated. In the process of the constructive political communication, including through forums, charitable and volunteer actions, young people and politicians can exchange positive experiences, be heard, and get real results of their activities.

Defining social communication Shilova considers it as a process that connects separate parts of social systems with each other; it is a mechanism through which power is realised (power as an attempt to determine the behaviour of another person) [Shilova, 2004]. Thus, political practices can be viewed as a means of communication between politically active youth and the government / state.

The political sphere is one of the spheres of self-realization of youth. The unstable political situation in the country and the world worries more than a quarter of young people $(26.5 \%)$ and every fourth $(21.1 \%)$ is concerned about the imperfection of the state [Chueva, 2017]. In addition, one in four young people $(24.1 \%)$ considers the situation with corruption in the country, as a characteristic of domestic political life, the most worrisome at the moment. Youth political movements and public organisations have been created and are functioning in Russia and political associations provide channels of social mobility for young people. At the same time, they do not feel themselves to be active participants in political life, an actor and a subject capable of influencing decisions made in public and political life. Thus, a study of the values of young people showed that a third of young people aged 16 to 24 is more likely to approve of the values of the modern Russian state, but $28.2 \%$ do not approve. At the same time, in the event of unfavourable unforeseen social upheavals, every fifth young person $(21.3 \%)$ expressed readiness to take part in protest actions. 
Participation in political rallies is one of the forms of political activity of young people which is gradually beginning to develop in modern Russia. According to the results of a study of the value orientations of Russian youth [Chueva, 2017], more than half (52.4\%) of the surveyed young people aged 16 to 24 did not participate in political rallies and are categorically against such actions. Only $4 \%$ of respondents often take part in political rallies, and $8 \%$ indicated that they tried to participate or rarely participate. A quarter of young people surveyed, not participating in political rallies, do not blame others for such participation. Since young people aged 16 to 24 are in the stage of forming a worldview, it is very important for state and public organisations and political leaders to take measures to create mechanisms for their constructive participation in the country's political life and to prevent destructive manifestations during mass political events.

P. Bourdieu [Burd'yo, 1993] spoke about the dualism of the political sphere where on one side there is the political sphere characterised by institutionalisation, approved and supported by the state, but on the other side, the marginal political sphere, that is, extra-institutional, extra-systemic and extra-ideological [Vafin, 2011]. The dualism of the political sphere is increasing, and the line of demarcation becomes more and more illusory as a result of the shift of politics to the digital sphere.

According to a study of the value orientations of Russian youth [Chueva, 2017], young people show a moderate interest in politics - half of the respondents indicated that they are interested in politics from time to time (48.9\%), and every third is not interested in politics at all. Thus, the majority of young people aged 16-24 are rather apolitical. Despite this, almost $17 \%$ of the respondents closely follow the political life in Russia and in the world, and less than $4 \%$ take an active part in political activities. The shift of politics to the digital space increases the participation of young people (aged 18-30) in it, since digitalisation is one of the main characteristics of modern youth, which means that the emergence and development of its political activity takes place precisely in the social media space.

The growth of civic engagement and political participation of young people is expressed primarily in the digital and not only political practices they use.

The political practices of youth have the following characteristics:

1. Virulence: the political mood of young people as a reaction to loud, significant or resonant events spreads extremely quickly across the Web becoming similar to a media virus; 
2. Diversification: the repertoire of digital political practices of young people is constantly expanding creating the danger of their non-linear and unpredictable spread;

3. Hybridity: digital political practices of youth are carried out on the border of the street and social media;

4. Non-normativeness and fronting: digital political practices of young people cannot be unequivocally defined as constructive or destructive; at the moment, their research is between knowledge and ignorance, which makes it difficult to predict and regulate youth political participation.

Based on the characteristics identified, it can be concluded that the digital political practices of young people are marginal. But, if traditionally sociologists (G. Simmel [Zimmel], P. Bourdieu etc.) consider marginality as a borderline state, when a subject being outside moves to the border of something systemic and non-marginal, then we [Blinova, 2019; Kruzhkova, 2019] in our study understand the phenomenon of marginality from the standpoint of political anthropology focusing not on its constructive or destructive nature, but on its content. In this regard, marginality, in relation to the digital political practices of youth, is understood by us as a form of non-institutional interaction in the digital space, the result of which is the reproduction and transfiguration of political relations by young people, the acquisition of civic identity and the realization of civic subjectivity. Marginal political practices of young people in the digital space are becoming a new norm in the era of post-politics, post-democracy and post-ideology turning from a rare case into a communication trend.

\section{Study material, methodology and research technique}

The material of the study was publications in social networks, forums, blogs and vlogs representing significant political events for Russia - the 'SQUARE conflict' in Ekaterinburg in May 2019, elections to the Moscow City Duma in August 2019, the introduction of restrictive measures in the context of the COVID-19 pandemic, protests in Khabarovsk, voting on amendments to the Constitution, protests in the Republic of Belarus.

Trend watching, as the main research procedure, made it possible to establish that the marginal nature of the political practices of young people and, above all, the uncertainty of normative assessments reveal contradictions in legal regulation in this area. 


\section{Research results and the discussion of the results}

As a result of the analysis of individual cases, we have identified the following marginal political practices of young people:

1. Petition practices on the resources of Change.org and ROI used to attract more participants in the action.

2. Hashtags used to identify themselves and their position in a political conflict, and the 'hashtag war'. For example, \#YazaSkver, \#YazaKhram or \#Ihavetherighttochoose, \#liveBelarus, \#YaMyBatka etc.

3. Battle of sticker packs, i. e. using stickers in messengers to express their position. For example, Telegram Channel users have access to sets of stickers reflecting both the position of the authorities in the conflict in Belarus ('Defend the Old Man!') and protest ideas ('Father, resign!').

4. Flash mobs performing a mobilisation function, for example, the organisation of walks, meetings, etc., serving to indicate the seriousness of their intentions and their visualisation to government institutions.

5. Cyberbullying, trolling, holivar implemented through bullying, threats spreading across the Network, including also physical violence against participants in the actions, as a rule, either opponents or representatives of the state.

6. Memo Practices - creation and replication of political memes as a reaction to what is happening and the representation of their subjective position in the conflict. For example, the image of the location of temples in the centre of Ekaterinburg in the form of a symbol of Baphomet - an inverted pentagram, a paraphrase of the famous saying 'There is no choice, but you cheer up!', the meeting of A. Lukashenko and V. Putin in Sochi in a cosplay of a meme about two dogs of the Siba Inu breed - sickly Chims and pumped-up Doge.

7. Streams, posts and reposts on online news platforms and social networks, i. e. conducting online broadcasts from places where the main events take place, or a chronotope of events in real time distributing photos and positions of LOMs in their accounts.

8. The practice of creating and distributing fake news. This practice is used either to draw more attention to the conflict or to escalate it.

9. Digital remote rallies, including Yandex rallies. As an example, opposing the procedure for issuing passes, the lack of guarantees for the preservation of wages and jobs, complaining about financial difficulties in the context of a pandemic and the introduced 'self-isolation regime', residents of Moscow, St. Petersburg, Ekaterinburg, Rostov-on-Don, Krasnoyarsk, Nizhny Novgorod 
and other cities used the 'Conversations' function in the mobile version of 'Yandex.Maps' and 'Yandex.Navigator' which allows you to put a point on the map (for example, near the building of the regional government) and write a protest commentary on it ('Finish with this! No money, no work! What to live on?', 'Feed my cats, and I will stay at home!' 'Either an emergency, or pay the loans and utility bills yourselves!', 'You can't even run alone' etc.).

Digital political practices of young people appearing in the Internet space, spreading within it and uniting like-minded people cannot fully realize themselves and achieve their goals while remaining on the Internet, for this they need to go beyond its limits into the offline space. Here they are reduced, as a rule, to the practice of protest behaviour. Protest behaviour can be considered as behaviour characterised by the dissatisfaction of a social group with the current state of affairs, unjustified expectations and at the same time a willingness to take concrete actions to change a subjectively perceived negative situation [Gaba, 2015]. In other words, protest for young people is a way of self-presentation, on the one hand, and a way of verbalising and accentuating their position, on the other.

The choice of protest by young people as the main political practice is not accidental, but it is conditioned by internal and external factors, namely, the social status of this social group, as well as the position occupied by the authorities in political conflicts. As for internal factors, they follow from the characteristics of young people as a social group. Young people are characterized by a lack of political knowledge and excessive emotionality, which together give a sharp and unpredictable reaction to what is happening. The marginality of political practices allows various unscrupulous power or opposition groups to manipulate the political activity of young people and, speculating on the desire of young people to change the situation in the country for the better, to direct it in accordance with their own selfish goals. Another characteristic of youth is dynamism and perspective. Since a young age is a period of acquiring civic identity, the formation of civic subjectivity and the formation of a social and political position, young people act as drivers of state development, striving to modernise the existing political structure through vigorous activity.

Therefore, the socio-political guidelines chosen by them determine the future development of the country and society. Besides, the practice of protest behaviour is close to young people due to their non-conformity and inclination to take unjustified risks in defending their interests and fighting 
for justice. Ignoring the demands of young people on the part of the authorities, or the use of punitive measures, can lead to riots and violent confrontation between youth and the authorities, as it happened in the SQUARE conflict and the conflict over the elections to the Moscow Duma. Finally, the social inequality felt by young people relative to other social groups also gives rise to protest in order to define their view of the situation and force other people to hear and see them. The social inequality is expressed in their borderline position between childhood and adulthood, in connection with which the representatives of the authorities prefer to either not notice nor hear them, nor not give their speeches serious significance. For example, at the fifth Eastern Economic Forum (EEF) held in Vladivostok on September 4-6, 2019, President of the Russian Federation V. V. Putin advised young people not to waste energy on protests, but to direct it to increasing the birth rate. It can be assumed that the President, as the highest official in the state, voiced the position of the official authorities regarding the expression of their political position through their protest behaviour. At the same time, it may be sensible (without reference to young people) to engage in a controversy with the authorities on this issue. It should be noted that protest for politically active youth is a democratic way to declare a position and invite the authorities to a constructive dialogue, and not an idle pastime. The authorities must remember that, on the one hand, young people are, according to K. Mannheim [Manhejm, 2010], a hidden resource of society on which its vital activity depends, but on the other hand, according to G. Marcuse [Markuze, 2003], they are a new revolutionary force, and therefore, a refusal for a dialogue and replacing it with populist speeches or 'festival' meetings, can lead to tragic consequences.

The authorities are not able to overcome internal factors since they are generated by the internal specifics of young people and their attitude to social and political problems; yet by their behaviour, by competently building interaction with young people, the authorities and officials can minimize these problems, ceasing to perceive young people as an insignificant socio-political force whose aspirations and demands are not essential and do not deserve to be heard and resolved.

S. Huntington [Hantington, 2018] said that people's demands grow faster than the government's ability to fulfil them. Nevertheless, the authorities must necessarily have the function of strategic thinking and forecasting in order to understand that young people are not an idle bored mass, but 
a resource of citizenship for the sake of which and thanks to which the state will develop in the future.

'The picture of the future formed by today's youth also determines what Russia will be like in 10 to 20 years. Through children and youth, the country reproduces itself, and it will depend on what values the young generation will accept today', said Pyotr Tolstykh* on youth policy in Russia at an expanded parliamentary hearing in the State Duma back in 2017.

As for external factors, they should include, firstly, a sense of the falsity of the events taking place and a sense of violated social justice that arise among young people, and not only among them. Unpopular reforms, humanitarian actions carried out by the state, and positioned as a benefit for the country and the people, undermine the credibility of the authorities. '... Those values and ideas that seem convincing, lofty and fascinating to the country's leadership are simply alien and therefore do not arouse any interest in the milieu upon which they are trying to impose, and primarily among urban youth' [Krasheninnikov, 2017]. A sense of injustice also arises due to the adoption of ambiguous laws (for example, the one which enters into force from 1 November 2019, namely, No. 90-FZ of 1.05.2019 On Amendments to Federal Law No. 126-FZ' On Communications' and Federal Law No. 149 -FZ On Information, Information Technology and Information Protection - the law on the sovereign Internet) and their ambiguous interpretation and application. Every seventh young person is worried about restrictions and control by the state (15.2\%). For example, Maria Motuznaya was accused for her reposting on social networks, her case being subject to Article 282 of the Criminal Code of the Russian Federation; and administrative proceedings were brought up against Lev Gammer for violation of No. 30 - FZ On Amendments to Federal Law No. 149-FZ On Information, Information Technologies and Protection of Information (Law on Insult to the authorities). But none of the officials who permitted themselves to insult society and its citizens, also protected by No. 30-FZ, were punished.

Secondly, a factor in the protest behaviour of young people is the negative moral and ethical image of the authorities broadcasting their disrespect, inability, and in some cases, unwillingness to talk to young people about the problems that concern them. Statements like 'the state didn't ask you

* https://xn-b1aecn3adibka9mra.xn-1ai/blog/43288601502/Gosudarstvo-i-molodyozh:-popyitki-dialoga 
to give birth,' 'no money, you need to eat less,' 'you don't like the prices, then you earn little,' 'while you pay on the mortgage, you can take your children to the orphanage' are very clear examples.

Statements of politicians, their behaviour during high-profile and 'significant for young people' actions (the policy of non-intervention of A. Vysokinsky, the mayor of Ekaterinburg, in the conflict over the construction of the temple which led to its escalation, or the forceful measures taken by the authorities of Moscow during protest events) and the tendency to avoid solving problems but protecting themselves from young people marginalise the authorities themselves, making them objects of memes and various types of bullying and thus undermining their credibility. It can be assumed that the ideas of young people about the corruption in the country and state structures intensify the fear of not realizing themselves in life.

The control of external factors is completely in the hands of the authorities. The health of a society depends on the quality of power. A firm, accountable and decisive government with a socially significant goal has a positive effect on society. On the contrary, the vacillating, incompetent, self-serving government which has made quick enrichment a fetish negatively affects the stability of society and undermines the confidence of the masses in the supreme institutions [Safronov, 2006]. What can be proposed to the authorities to undertake so as to rationalize the youth practice of protest behaviour and make it constructive?

First, the authorities need to stop being afraid of young people, stop ignoring them and recognise their right to civic subjectivity and political activity. They should recognise that youth is human capital that will ensure the development of Russia in the future, and for this it is necessary to know and accept the values in accordance with which modern young people live, and not to reproach them with the notorious traditional values of a country that has passed away and is alien to them, and not to oppose the values of today's youth with state violence because this practice is short-lived and will turn against the authorities and the state.

Secondly, the authorities need to abandon the punitive policy towards politically active youth. Today, the government considers all manifestations of political activity of young people through a legal prism qualifying this or that marginal practice in accordance with the articles of the Criminal Code of the Russian Federation or the Code of Administrative Offenses of the Russian Federation. If the corresponding article is not found, it is immediately 
issued; so it was with the adoption of the so-called Law on the Protection of Power and with amendments to Art. 13.15 of the Administrative Code on punishment for spreading fake news. At the same time, the authorities prefer not to notice that such legislative activity not only does not solve the problem of marginal political behaviour of young people, but also endangers the democratic foundations of the state and aggravates the conflict situation forcing young people to engage in more and more marginal practices. Due to the flexibility and creativity of thinking, young people will find new ways to protest against inaction or injustice of government regulation. As a result, instead of organising joint productive work, the authorities are driving themselves and the youth into a bad infinity of confrontation.

The third step can be social partnership, i.e. interaction based on the desire of the parties to reach agreement [Shchenina, 2011]. Social partnership is based on cooperation between the authorities and youth as equal subjects of the political process. Realization of social partnership can be achieved by involving young people in the process of their concerns. In Russia, such a direction of political power as youth policy is developing, there are a large number of youth organisations, like the youth parliament, Rosmolodezh, and the Young Guard, etc. Nevertheless, there is no need to talk about the effectiveness of youth policy. The reason for this is the lack of clear goals for the activities of youth policy bodies and of the criteria for assessing the effectiveness of these activities. There is no clear algorithm for involving youth organisations in socio-political activities. There is no normative legal act governing the functioning of youth organisations in the Russian Federation (today there is only the Strategy for the Development of Youth of the Russian Federation for the Period up to 2025). Exercising control over the activities of youth political organisations, government institutions determine the directions of this activity and its quality, which reduces the effect of the institutionalized political activity of young people to naught pushing them to use marginal practices. There are no effective youth leaders who can articulate the interests and needs of youth. In other words, we can talk about the absence of a system of youth policy in Russia, and accordingly, the authorities solve the problems of youth on a situational basis.

The fourth step in overcoming the protest behaviour of youth as the most popular marginal political practice is a constructive dialogue between the authorities and youth characterised by a high level of interest of the parties in reaching agreement. A dialogue in the political sphere is a reasonable 
alternative to violence, war, terrorism, revolutions, uprisings, riots and other manifestations of political extremism, radicalism, impatience and intolerance. At the same time, dialogue in politics does not mean a conversation between two or more persons on political issues, but a certain configuration of interaction, a negotiation process and partnership based on the principles of discursive equality between the subjects of political communication striving for mutual understanding and achieving a mutually beneficial result and taking into account a wide range of existing opinions and interests [Zajcev, 2013]. Today the political dialogue is difficult for the following reasons. First, is mutual distrust. The authorities do not trust young people since they are an unstable social group capable of destabilizing the socio-political situation. Young people do not trust the authorities since the authorities have run out of the confidence vote and are not perceived by young people as an institution capable of rational management for the benefit of society. Secondly, the weak level of civil society development. Despite the fact that Russia is positioned as standing by the democratic rule of law, real democracy, civil society and the rule of law are not its integral characteristics. A specific feature of civil society is its formation on the basis of an association of citizens, while in Russia it arose 'from above' and, accordingly, cannot perform its intended functions. Youth organisations are institutions of civil society the purpose of which is to represent and lobby their interests before the authorities, but due to the specifics of the development and functioning of civil society in Russia, the authorities are not ready to hear them.

\section{Conclusion}

Summing up, the following conclusions can be drawn. First, the political practices used by young people to defend their interests are marginal. Secondly, the most common and effective political practice of young people in the offline space is protest behaviour. Thirdly, the marginality of the political practices of young people makes it difficult to predict and regulate them, which can lead to riots and destabilization of the situation in the state. Fourthly, the excessive legalization of attitudes towards marginal practices leads to the opposite effect, escalating the marginality of young people. Because of this, the political practices of young people are marked by the authorities as negative and threatening, and therefore subject to forceful confrontation. Fifth, the most effective ways to overcome the negative consequences of pro- 
test behaviour are social partnership and constructive dialogue between the authorities and youth.

\section{Conflict of Interest}

The authors have no conflict of interest to declare.

\section{Acknowledgment (s)}

The study was supported by the Russian Foundation for Basic Research and ANO EISI (Autonomous Non-Commercial Organisation, Expert Institute for Social Research), Project no. 20-011-31736.

\section{References:}

1. T. Shibutani. Social'naya psihologiya [Social psychology]. AST, Moscow; Feniks, Rostov-on-Don (1999).

2. V.A. Shilova. O semiosociopsihologicheskom podhode k izucheniyu processov kommunikacii [Concerning the semiosociopsychological approach to the study of communication processes]. Rossijskoe obshchestvo i sociologiya v XXI veke: Social'nye vyzovy i al'ternativy. Materialy II Vseros. sociol. kongr. [Russian society and sociology in the XXI century: Social challenges and alternatives: Proceedings of the II Russian Congress on Sociology], MGU, Moscow (2004).

3. Cennostnye orientacii rossijskoj molodezhi i realizaciya gosudarstvennoj molodyozhnoj politiki: rezul'taty issledovaniya [Value orientations of Russian youth and the implementation of state youth policy: research results]. State University of Management [edited by. S. V. Chueva]. Izdatel'skij dom GUU, Moscow (2017).

4. P. Burd'yo. Sociologiya politiki [Political sociology]. Socio-Logos, Moscow (1993), http://bourdieu.name/content/sociologija-politiki (Accessed 26 August 2020).

5. A. M. Vafin. Politicheskaya marginal'nost': teoreticheskie i prakticheskie aspekty [Political marginality: theoretical and practical aspects]. Polis. Politicheskie issledovaniya [Polis. Political research], № 4 (2011), pp. 137-143, https://cyberleninka.ru/article/v/politicheskaya-marginalnost-psihologiya-i-ideologiya (Accessed 26 August 2020).

6. G. Zimmel. Ekskurs o chuzhake [Excursion about a stranger] Sociologicheskaya teoriya: istoriya, sovremennost', perspektivy. Al'manah zhurnala "Sociologicheskoe obozrenie" [Sociological theory: history, modernity, prospects. Almanac of the journal “Sociological Review”]. Vladimir Dal, Saint Petersburg (2008), pp. 7-13.

7. O. A. Blinova, Y. A. Gorbunova, R. Y. Porozov, A. G. Obolenskaya. Digital political practices of Russian youth: YouTube top bloggers. Proceedings of the 1st 
international scientific practical conference "the individual and society in the modern geopolitical environment”. ISMGE (2019), https://www.atlantis-press.com/proceedings/ismge-19/125912448 (Accessed 1 September 2020).

8. O. V. Kruzhkova, I. V. Vorobieva, M. S. Krivoshchekova. Politicheskaya aktivnost' sovremennoj molodezhi i marginal'nye politicheskie praktiki [Political activity of modern youth and marginal political practices]. Pedagogicheskoe obrazovanie [Pedagogical Education], № 9 (2019).

9. O. I. Gaba. Molodezh' kak sub"ekt protestnyh nastroenij [Youth as a subject of protest moods]. Znanie. Ponimanie. Umenie [Knowledge. Understanding. Skill], № 1 (2015), pp. 144-152, https://cyberleninka.ru/article/v/molodezh-kak-subekt-protestnyh-nastroeniy (Accessed 26 August 2020).

10. K. Manhejm. Izbrannoe: Diagnoz nashego vremeni [Selected: Diagnosis of our time]. Izd-vo RAO “Govoryashchaya kniga”, Moscow (2010), http://yakov. works/libr_min/13_m/an/heim3.html (Accessed 1 September 2020).

11. G. Markuze. Odnomernyj chelovek [One dimension human]. AST, Ermak, Moscow (2003).

12. S. Hantington. Stolknovenie civilizacij [Clash of civilisations]. AST, Moscow (2018).

13. F. Krasheninnikov. Vlast' i molodezh': nelyubov' [Power and youth: dislike]. Vedomosti (2017) https://m.vedomosti.ru/opinion/columns/2017/06/14/694232-vlast-molodezh (Accessed 27 August 2020).

14. A. P. Safronov. Marginalizaciya verhovnoj vlasti kak predposylka obshchestvennogo raskola [Marginalization of the supreme power as a prerequisite for social split]. Aktual'nye problemy sovremennoj nauki [Actual problems of modern science], № 5 (2006), pp. 43-52, http://naukarus.com/marginalizatsiya-verhovnoy-vlasti-kak-predposylka-obschestvennogo-raskola (Accessed 26 August 2020).

15. O.G. Shchenina. Molodezhnaya politika: dialog s molodezhyu ili monolog vlasti? [Youth Policy: Dialogue with Youth or Power Monologue?]. Rossiya: tendencii i perspektivy razvitiya [Russia: tendenies and perspectives of development] (2011), pp. 181-186, https://cyberleninka.ru/article/v/molodezhnaya-politika-dialog-s-molodezhyu-ili-monolog-vlasti (Accessed 29 August 2020).

16. A. V. Zajcev. Gosudarstvo i grazhdanskoe obshchestvo: deficit dialoga [State and civil society: lack of dialogue. Gumanitarnye nauchnye issledovaniya [Humanitarian research], № 8 (2013), http://human.snauka.ru/2013/08/3703 (Accessed 27 August 2020). 